\title{
Analisis Perbedaan Motivasi Belajar Siswa Kelas XI IPA 1 dan XI IPA 2 di MAN 1 Merangin
}

\author{
Sri Muslimatul Husna ${ }^{1,{ }^{*}}$, Lodiana Siahaan $^{1)}$, Ulfah Saniyyah $^{1)}$, Aldi Muhamat Kurniawan ${ }^{1)}$ \\ ${ }^{1)}$ Universitas Jambi, ${ }^{2)}$ Universitas Jambi, ${ }^{3)}$ Universitas Jambi, ${ }^{4)}$ Universitas Jambi \\ *srimuslimatulhusna11@gmail.com
}

Abstrak: Penelitian ini bertujuan untuk melihat perbedaan hasil motivasi belajar siswa kelas XI IPA 1 dan kelas XI IPA 2 di MAN 1 Merangin pada mata pelajaran fisika. Penelitian ini dilakukan secara online mulai tanggal 4 Februari sampai dengan 31 Maret 2021 pada semester genap tahun ajaran 2020/2021. Instrumen yang digunakan adalah angket tentang motivasi belajar fisika. Sampel penelitian ini adalah 27 siswa kelas XI IPA 1 dan 27 siswa kelas XI IPA 2 MAN 1 Merangin tahun pelajaran 2020/2021, sehingga total jumlah sampel sebanyak 54 responden, sedangkan populasinya adalah seluruh siswa MAN 1 Merangin. Penelitian ini menggunakan metode penelitian kuantitatif dengan jenis penelitian survei. Teknik analisis data yang digunakan peneliti adalah teknik purposive sampling. Analisis data dilakukan dengan menggunakan software IBM SPSS 23, dengan melakukan uji-f atau uji one way ANOVA. Dari hasil uji-f atau uji one way ANOVA, maka diperoleh yaitu $\mathrm{F}$ hitung sebesar 0,803 sedangkan $\mathrm{F}$ tabel sebesar 4,03 sehingga diketahui $\mathrm{F}$ hitung $<\mathrm{F}$ tabel atau 0,803 4,03 maka $\mathrm{H}_{0}$ diterima, artinya tidak ada perbedaan rata-rata hasil motivasi belajar fisika kelas XI IPA 1 dan kelas XI IPA 2. Adapun nilai probabilitas atau signifikansi sebesar 0,374 >0,05. Dengan demikian hipotesis nol $\left(\mathrm{H}_{0}\right)$ diterima. Hasil penelitian ini menunjukkan bahwa tidak ada perbedaan rata-rata hasil motivasi belajar fisika kelas XI IPA 1 dan kelas XI IPA 2.

Kata Kunci: Motivasi Belajar Siswa, MaPelajaran Fisika.

\section{PENDAHULUAN}

Pendidikan adalah suatu kegiatan yang sangat penting bagi setiap manusia, dengan adanya pendidikan manusia dapat merubah tingkah laku dan pengetahuan menjadi lebih baik (Kurniawan et al., 2019). Pendidikan adalah suatu proses untuk memperbaiki kualitas kehidupan, serta memperoleh dan menanamkan keterampilan yang dilakukan oleh peserta didik (Kurniawan et al., 2018b). Pendidikan adalah suatu proses integral yang berkaitan dengan beberapa faktor seperti tujuan pendidikan, tenaga pendidik, peserta didik, alat pendidikan, serta lingkungan pendidikan (Nehru \& Irianti, 2020). Oleh sebab itu, pendidikan menjadi salah satu kebutuhan pokok bagi setiap individu karena berkaitan erat dengan kehidupan suatu bangsa, tanpa adanya pendidikan, maka setiap individu akan mengalami kesulitan untuk turut aktif berpartisipasi di era globalisasi serta sulitnya memperoleh kesempatan (Kurniawan \& Pathoni, 2019). Selain itu, pendidikan yang berkualitas sangat ditentukan oleh kualitas seorang guru dalam mengajar, karena guru merupakan ujung tombak yang akan menentukan keberhasilan dalam pembelajaran dan guru yang akan berhubungan langsung dengan dengan peserta didik (Dani et al., 2020). Pendidikan itu sendiri tidak luput dari belajar dan pembelajaran.

Belajar adalah kegiatan yang tidak mengenal batas umur dan suatu yang berlangsung seumur hidup melalui interaksi dengan lingkungan yang dapat merubah kebiasaan atau perilaku seseorang, sedangkan pembelajaran adalah perkembangan pengetahuan, dan keterampilan baru pada saat seorang berinteraksi dengan informasi atau lingkungan (Pakpahan et al., 2020). Lingkungan belajar merupakan suatu bagian dari proses belajar yang dapat menciptakan tujuan belajar, serta tidak lepas dari keberadaan siswa dalam belajar (putri,

Pembelajaran fisika menjadi salah satu pembelajaran yang penting di sekolah. seiring dengan perkembangan ilmu pengetahuan dan teknologi, fisika menjadi salah satu ilmu yang telah berkembang begitu pesat, baik dari segi materi maupun kegunaannya. Oleh karena itu, fisika merupakan salah satu ilmu yang seharusnya menarik untuk dikuasai oleh semua siswa (Purwanto et al., 2016). 
Fisika merupakan salah satu cabang ilmu pengetahuan alam yang mempelajari berbagai gejala-gejala alam yang terjadi disekitar kita (Utami et al., 2017b). Mata pelajaran fisika seringkali dianggap sulit oleh sebagian besar siswa disekolah menengah atas (SMA) (Dewi Sasmita Pasaribu et al., 2017). Berdasarkan wawancara dengan beberapa siswa didapat bahwa pelajaran fisika itu sulit, menyeramkan, tidak menarik, serta membosankan, sehingga fisika menjadi mata pelajaran yang tidak disenangi, ditakuti, bahkan dibenci (Kurnia et al., 2016b). Hal ini dikarenakan banyak siswa menganggap bahwa pembelajaran fisika itu hanya untuk siswa yang memiliki kemampuan di bidang fisika yang dapat dengan cepat memahami fisika. Selain itu, guru dalam mengajar fisika hanya menjelaskan materi dengan menggunakan rumus-rumus dan kurang menjelaskan konsep materi fisika serta aplikasi dalam kehidupan sehari-hari, sehingga siswa merasa kesulitan untuk memahami, dan mudah merasa monoton. Selain itu, faktor yang melatarbelakangi sulitnya siswa dalam memahami pelajaran fisika adalah kurangnya motivasi belajar.

Akibat dari rendahnya motivasi belajar siswa dalam memahami materi pelajaran fisika, maka akan berdampak pada hasil belajar peserta didik. Motivasi belajar sendiri merupakan dorongan yang diberikan oleh seseorang untuk lebih giat dalam belajar untuk mencapai prestasi terbaik. Oleh sebab itu, motivasi belajar menjadi peranan penting dalam memberi gairah, semangat, dan rasa senang dalam belajar. Rendahnya motivasi belajar fisika juga disebabkan oleh kurangnya pemahaman tentang hakikat, kemanfaatan, keindahan, dan lapangan kerja yang dapat dihasilkan dari belajar fisika. Dampak dari rendahnya motivasi belajar siswa yaitu menurunnya prestasi belajar siswa. Dari berbagai dampak yang ditimbulkan dari rendahnya motivasi belajar, maka diharapkan setiap peserta didik dapat meningkatkan motivasi dalam belajarnya terutama dalam belajar fisika. Jika seorang peserta didik yang memiliki motivasi belajar yang tinggi, maka mereka akan menjalankan tugas yang diberikan oleh guru walaupun seberat apapun tugas tersebut. Kegembiraan atau kenikmatan dalam proses belajar menjadi faktor yang sangat penting, terutama dalam bidang sains. Oleh karena itu, pentingnya penerapan motivasi untuk meningkatkan kesenangan dalam proses belajar sains.

Berdasarkan uraian diatas, penelitian ini bertujuan untuk memperoleh gambaran terkait perbandingan motivasi belajar siswa terhadap mata pelajaran fisika di MAN 1 Merangin. Dari hasil penelitian ini, dapat diketahui apakah ada perbedaan atau tidak terhadap rata-rata hasil motivasi belajar fisika pada kelas XI IPA 1 dan XI IPA 2 di MAN 1 Merangin. Untuk mengetahui perbedaan rata-rata hasil motivasi belajar tersebut, maka peneliti akan melakukan uji- $f$ atau uji one way anova dengan menggunakan software SPSS 23.

\section{METODE}

Penelitian ini dilaksanakan di Madrasah Aliyah Negeri 1 Merangin yang bertempatan di Kota Bangko, Kab. Merangin. Penelitian dilaksanakan pada tanggal 4 Februari s.d 31 Maret 2021 pada semester genap tahun ajaran 2020/2021 secara online. Tujuan dari dilakukan penelitian ini yaitu untuk mengetahui ada atau tidaknya perbedaan hasil motivasi belajar siswa pada mata pelajaran fisika pada kelas XI IPA 1 dan kelas XI IPA 2 di MAN 1 Merangin. Penelitian ini menggunakan metode kuantitatif, dengan jenis penelitian yaitu penelitian survei. Dalam KBBI survei dapat diartikan sebagai suatu teknik penelitian yang secara jelas membatasi data yang akan dikaji dan diamati. Populasi dalam penelitian ini adalah seluruh siswa MAN 1 Merangin. Sedangkan sampel atau bagian kecil yang diambil untuk mewakili populasinya yaitu siswa kelas XI IPA 1 dan XI IPA 2 dengan jumlah responden 27 orang perkelas, sehingga jumlah total sampel yang digunakan yaitu 54 siswa.

Teknik dari pengumpulan data pada penelitian ini yaitu menggunakan teknik purposive sampling. Penelitian dilakukan dengan cara mengumpulkan data menggunakan instrument penilaian tes berupa kuisioner atau angket tentang motivasi belajar yang berjumlah 32 item ini menggunakan skala likert. Skala tersebut terdiri dari 4 poin dengan pernyataan positif nilai sangat setuju 4, setuju 3, tidak setuju 2, dan sangat tidak setuju 1 . Sedangkan untuk bobot pernyataan negative adalah 1 sangat setuju, 2 setuju, 3 tidak setuju, 4 sangat tidak setuju.

Dalam melakukan penelitian ini, langkah pertama yang harus dilakukan oleh seorang peneliti yaitu menyebarkan kuesioner secara online melalui google form karena dalam masa pandemik. Setelah melakukan penyebaran kuisioner akan diperoleh sebuah data yang diinginkan. Langkah selanjutnya, menganalisis data dengan menggunakan SPSS dengan analisis jenis one way anova atau biasa disebut uji-f. Kemudian, diperoleh hasil analisis motivasi belajar fisika dengan menggunakan SPSS.

Pada penelitian ini menggunakan uji-f. Uji-f ini akan menentukan rata-rata skor motivasi belajar fisika dari dua grup yang tidak saling berhubungan satu dengan yang lain dengan tujuan untuk membuktikan apakah 
motivasi belajar fisika siswa dikelas yang satu dengan kelas yang lain memiliki perbedaan atau tidak dalam pembelajaran fisika yang ada disekolah MAN 1 Merangin. Adapun hipotesis yang digunakan dalam uji-f, yaitu sebagai berikut:

$\mathrm{H}_{0}=$ Tidak ada perbedaan rata-rata hasil motivasi belajar fisika kelas XI IPA 1 dan kelas XI IPA 2.

$\mathrm{H}_{1}=$ Ada perbedaan rata-rata hasil motivasi belajar fisika kelas XI IPA 1 dan kelas XI IPA 2.

Untuk menentukan $\mathrm{H}_{0}$ atau $\mathrm{H}_{1}$ yang diterima, maka terdapat beberapa ketentuan yang harus diikuti, yaitu sebagai berikut:

1. Jika $\mathrm{F}_{\text {hitung }}>\mathrm{F}_{\text {tabel }}$, maka $\mathrm{H}_{0}$ ditolak.

2. Jika $\mathrm{F}_{\text {hitung }}<\mathrm{F}_{\text {tabel }}$, maka $\mathrm{H}_{0}$ diterima.

3. Jika signifikan atau probabilitas $>0,05$, maka $\mathrm{H}_{0}$ diterima.

4. Jika signifikan atau probabilitas $<0,05$, maka $\mathrm{H}_{0}$ ditolak.

\section{HASIL DAN PEMBAHASAN}

Motivasi belajar diukur dengan menyebarkan angket secara online melalui google form yang berjumlah 32 pernyataan ke siswa. Angket motivasi disebar dan diukur untuk menganalisis perbedaan motivasi belajar siswa kelas XI IPA 1 dan kelas XI IPA 2 di MAN 1 Merangin terhadap mata pelajaran fisika. Untuk melihat hasil output descriptives dari uji perbandingan menggunakan uji-f atau uji one way anova untuk motivasi belajar fisika siswa kelas XI IPA 1 dan kelas XI IPA 2 dapat dilihat pada tabel 1 dibawah ini:

Tabel 1. Descriptives Hasil Motivasi Belajar Fisika Kelas XI IPA 1 dan XI IPA 2 di MAN 1 Merangin

\begin{tabular}{|c|c|c|c|c|c|c|c|c|}
\hline \multicolumn{9}{|c|}{ Descriptives } \\
\hline \multicolumn{9}{|c|}{ Hasil Motivasi Belajar Fisika } \\
\hline & \multirow{2}{*}{$\mathrm{N}$} & \multirow{2}{*}{ Mean } & \multirow{2}{*}{ Std. Deviation } & \multirow{2}{*}{ Std. Error } & \multicolumn{2}{|c|}{ 95\% Confidence Interval for Mean } & \multirow[t]{2}{*}{ Min } & \multirow[t]{2}{*}{ Max } \\
\hline & & & & & Lower Bound & Upper Bound & & \\
\hline Kelas XI IPA 1 & 27 & 86.9630 & 5.33120 & 1.02599 & 84.8540 & 89.0719 & 75.00 & 97.00 \\
\hline Kelas XI IPA 2 & 27 & 88.0741 & 3.61541 & .69579 & 86.6439 & 89.5043 & 81.00 & 95.00 \\
\hline Total & 54 & 87.5185 & 4.54637 & .61868 & 86.2776 & 88.7594 & 75.00 & 97.00 \\
\hline
\end{tabular}

Berdasarkan Tabel 1. Output descriptives diatas memuat hasil-hasil data statistic deskriptif seperti mean, standar deviasi, angka terendah dan tertinggi. Pada bagian ini terlihat ringkasan statistic dari kedua sampel, dimana untuk kelas XI IPA 1 dan kelas XI IPA 2 memiliki jumlah sampel yang sama yaitu sebesar 27 sampel, sehingga total sampel sebesar 54 sampel. Untuk nilai mean kelas XI IPA 1 sebesar 86,9630 sedangkan kelas XI IPA 2 sebesar 88,0741, sehingga total mean kedua kelas yaitu sebesar 87,5185. Untuk standard deviation kelas XI IPA 1 sebesar 5,33120 sedangkan kelas XI IPA 2 sebesar 3,61541, sehingga diperoleh total standard deviation kedua kelas sebesar 4,54637. Untuk standard error kelas XI IPA 1 sebesar 1,02599 sedangkan kelas XI IPA 2 sebesar 0,69579, sehingga diperoleh total standard error kedua kelas tersebut sebesar 0,61868. Untuk data 95\% confidence interval for mean menunjukkan nilai lower bound untuk kelas XI IPA 1 sebesar 84,8540 sedangkan kelas XI IPA 2 sebesar 86,6439, sehingga diperoleh total lower bound kedua kelas tersebut sebesar 86,2776. Untuk nilai upper bound kelas XI IPA 1 sebesar 89,0719 sedangkan kelas XI IPA 2 sebesar 89,5043, sehingga diperoleh total upper bound kedua kelas sebesar 88,7594. Untuk nilai minimum kelas XI IPA 1 sebesar 75 sedangkan kelas XI IPA 2 sebesar 81, sehingga diperoleh total minimum kedua kelas sebesar 75. Untuk nilai maximum kelas XI IPA 1 sebesar 97 sedangkan kelas XI IPA 2 sebesar 95, sehingga diperoleh total maximum kedua kelas tersebut yaitu sebesar 97.

Setelah mengetahui hasil output descriptives, maka langkah selanjutnya melihat hasil output test of homogeneity of variances untuk motivasi belajar fisika siswa kelas XI IPA 1 dan kelas XI IPA 2 dapat dilihat pada tabel 2:

Tabel 2. Memperlihatkan test homogeneity of variances diatas, dimana tes ini menampilkan hasil uji homogenitas varians sebagai prasyarat untuk dapat menggunakan anova. Tes ini bertujuan untuk menguji berlaku tidaknya asumsi untuk Anova, yaitu apakah kedua sampel mempunyai varians yang sama atau tidak. 
Untuk melihat apakah kedua sampel yang ada mempunyai varian yang sama (homogeny) dapat diterima atau ditolak, maka pelu dipersiapkan hipotesis tentang hal tersebut. Adapun hipotesisnya adalah sebagai berikut:

$\mathrm{H}_{0}=$ Kedua varians populasi yaitu sama.

$\mathrm{H}_{1}=$ Kedua varians populasi yaitu tidak sama.

Dengan syarat pengambilan keputusan yaitu sebagai berikut:

1. Jika nilai signifikansi $>0,05$ maka $\mathrm{H}_{0}$ diterima.

2. Jika nilai signifikansi $<0,05$ maka $\mathrm{H}_{0}$ ditolak.

Tabel 2. Test of Homogeneity of Variances Hasil Motivasi Belajar Fisika Kelas XI IPA 1 dan XI IPA 2

\begin{tabular}{cccccc}
\hline \multicolumn{4}{c}{ Test of Homogeneity of Variances } & & \\
\hline & Levene Statistic & df1 & df2 & Sig. \\
\hline \multirow{2}{*}{ Hasil Motivasi } & Based on Mean & 3.344 & 1 & 52 & .073 \\
Belajar Fisika & Based on Median & 2.933 & 1 & 52 & .093 \\
& Based on Median and with adjusted df & 2.933 & 1 & 44.598 & .094 \\
\hline
\end{tabular}

Dari tabel 2 diatas dapat diketahui bahwa nilai levene statistic untuk based on mean sebesar 3,344, untuk based on median sebesar 2,933, untuk based on median and with adjusted df sebesar 2,933, dan untuk based on trimmed mean sebesar 3,348. Sedangkan nilai signifikan untuk based on mean sebesar 0,073, untuk based on median sebesar 0,093, untuk based on median and with adjusted df sebesar 0,094, dan untuk based on trimmed mean sebesar 0,073 .

Berdasarkan pada hasil yang diperoleh pada test of homogeneity of variances, dihasilkan bahwa semua probabilitas atau signifikannya, baik untuk based on mean, based on median, based on median and with adjusted df, maupun based on trimmed mean menghasilkan nilai signifikan >0,05, yang berarti lebih besar dari 0,05, maka dapat disimpulkan bahwa hipotesi nol $\left(\mathrm{H}_{0}\right)$ diterima, artinya asumsi bahwa kedua varians populasi adalah sama (homogeny) dapat diterima. Dengan demikian prasyarat untuk dapat menggunakan anova terpenuhi. Setelah prasyarat untuk dapat menggunakan anova terpenuhi berdasarkan nilai signifikan dari test homogeneity of variances, maka langkah selanjutnya melakukan uji-f atau biasa disebut uji one way anova. Untuk hasil output dari uji one way anova dapat dilihat pada tabel 3 dibawah ini:

Tabel 3. Uji-F Hasil Motivasi Belajar Fisika Kelas XI IPA 1 dan XI IPA 2 di MAN 1 Merangin

\begin{tabular}{cccccc}
\hline \multicolumn{5}{c}{ ANOVA } \\
\hline \multicolumn{5}{c}{ Hasil Motivasi Belajar Fisika } \\
\hline Sum of Squares & Df & Mean Square & F & Sig. \\
Within Groups & 16.667 & 1 & 16.667 & .803 & .374 \\
\hline Total & 1078.815 & 52 & 20.746 & & \\
\hline
\end{tabular}

Tabel 3. Memperlihatkan hasil yang diperoleh dari uji-f atau uji one way anova untuk hasil motivasi belajar fisika kelas XI IPA 1 dan kelas XI IPA 2 di MAN 1 Merangin. Uji one way anova atau uji-f ini dilakukan setelah kedua varians terbukti sama. Uji-f adalah pengujian terhadap koefisien regresi secara simultan yang bertujuan untuk mengetahui pengaruh semua variabel independen yang terdapat didalam model secara (simultan) terhadap variabel depennya, uji- $\mathrm{f}$ ini juga biasa disebut anova (analysis of variance) yang merupakan teknik analisis statistik yang menguji perbedaan rerata antar grup, grup yang dimaksud dapat berarti kelompok ataupun jenis perlakuan. Jadi dapat diketahui bahwa uji one way anova atau uji-f ini untuk menguji apakah kedua sampel dalam penelitian memiliki rata-rata yang sama atau tidak. Output one way anova ini merupakan akhir dari perhitungan yang digunakan sebagai penentuan analisis tehadap hipotesis yang akan diterima atau ditolak. Adapun hipotesis yang akan diuji yaitu sebagai berikut:

$\mathrm{H}_{0}=$ Tidak ada perbedaan rata-rata hasil motivasi belajar fisika kelas XI IPA 1 dan kelas XI IPA 2.

$\mathrm{H}_{1}=$ Ada perbedaan rata-rata hasil motivasi belajar fisika kelas XI IPA 1 dan kelas XI IPA 2. 
Untuk menentukan $\mathrm{H}_{0}$ atau $\mathrm{H}_{1}$ yang diterima, maka terdapat beberapa ketentuan yang harus diikuti, yaitu sebagai berikut:

1. Jika $\mathrm{F}_{\text {hitung }}>\mathrm{F}_{\text {tabel, }}$, maka $\mathrm{H}_{0}$ ditolak.

2. Jika $\mathrm{F}_{\text {hitung }}<\mathrm{F}_{\text {tabel}}$, maka $\mathrm{H}_{0}$ diterima.

3. Jika signifikan atau probabilitas $>0,05$, maka $\mathrm{H}_{0}$ diterima.

4. Jika signifikan atau probabilitas $<0,05$, maka $\mathrm{H}_{0}$ ditolak.

Berdasarkan pada hasil yang diperoleh pada uji one way anova sesuai pada tabel 3. Dapat dilakukan perbandingan terhadap hasil $\mathrm{F}$ hitung dengan $\mathrm{F}$ tabel, dimana diperoleh bahwa $\mathrm{F}$ hitung sebesar 0,803 , sedangkan $F$ tabel sebesar 4,03, sehingga diperoleh bahwa $F$ hitung $<F$ tabel atau $0,803<4,03$, maka $\mathrm{H}_{0}$ diterima, artinya tidak ada perbedaan rata-rata hasil motivasi belajar fisika kelas XI IPA 1 dan kelas XI IPA 2. Sedangkan untuk nilai probabilitas atau signifikannya sebesar 0,374>0,05. Dengan demikian hipotesis nol $\left(\mathrm{H}_{0}\right)$ diterima. Hal ini menunjukkan bahwa tidak ada perbedaan rata-rata hasil motivasi belajar fisika kelas XI IPA 1 dan kelas XI IPA 2.

Selain berdasarkan perhitungan statistik di atas motivasi belajar dari kelas XI IPA dan 1X IPA 2 tidak terdapat perbedaan. Hal tersebut diketahui karena guru yang mengajar di kelas tersebut sama. Artinya teknik mengajar atau kreativitas yang diterapkan oleh guru juga sama. Berdasarkan hasil penelitian Lukita \& Sudibjo menunjukkan bahwa kreativitas guru berpengaruh positif terhadap motivasi belajar siswa (Lukita \& Sudibjo, 2021, p. 158-159). Selain itu media pembelajaran yang guru gunakan juga turut mempengaruhi motivasi belajar siswa. Hal ini dapat dibuktikan dengan hasil penelitian Yuliani \& Winata menunjukkan bahwa media pembelajaran berpengaruh positif terhadap motivasi belajar siswa (Yuliani \& Winata, 2017, p. 32). Dalam artian apabila media pembelajaran menurun maka motivasi siswa untuk belajar pun turun atau rendah. Oleh karena itu kreativitas guru dalam menerapkan model pembelajaran, media pembelajaran, dan lain sebagainya yang dilibatkan dalam proses pembelajaran perlu dilakukan inovasi agar dapat meningkatkan motivasi belajar siswa.

\section{SIMPULAN}

Berdasarkan hasil penelitian menunjukkan bahwa tidak terdapat perbedaan motivasi antara kelas XI IPA 1 dan X IPA 2. Hal tersebut dapat dilihat dari hasil uji-f atau uji one way anova yaitu $F$ hitung $<F$ tabel atau $0,803<4,03$ maka H0 diterima. Adapun nilai probabilitas atau signifikansi sebesar 0,374>0,05. Dengan demikian hipotesis nol (HO) diterima. Tidak terdapatnya perbedaan motivasi antar kedua kelas tersebut karena guru yang mengajar juga sama sehingga perlakuan yang diberikan kepada kedua kelas sama. Diketahui juga bahwa kreativitas guru menerapkan model pembelajaran, media pembelajaran, dan lain sebagainya dapat mempengaruhi motivasi belajar siswa. Oleh karena itu guru perlu memiliki kreativitas dalam pembelajaran agar dapat membangkitkan motivasi belajar siswa.

\section{Ucapan Terima Kasih}

Peneliti mengucapkan terima kasih terutama kepada pihak dosen pengampu, serta terima kasih kepada kepala sekolah MAN 1 Merangin serta guru fisika di MAN 1 Merangin. Tidak hanya itu, peneliti juga mengucapkan terima kasih kepada responden yang telah membantu untuk kelancaran dalam proses penelitian ini, sehingga peneliti dapat menyelesaikan penelitiannya dengan tepat waktu.

\section{Daftar Pustaka}

Aminoto, T., Dani, R., \& Yuserva, E. (2019). PENGEMBANGAN TERMOMETER GAS SEBAGAI ALAT PERAGA PEMBELAJARAN POKOK BAHASAN SKALA SUHU MUTLAK. Jurnal EduFisika, 4(2).

Chotimah, C., Hendri, M., \& Rasmi, D. P. (2018). Penerapan LKS Berbasis Inkuiri Terbimbing pada Materi Listrik terhadap Hasil Belajar Siswa Kelas IX SMPN 22 Kota Jambi. Jurnal Penelitian Pembelajaran Fisika, 9(1).

Dani, R., Latifah, N. A., \& Putri, S. A. (2019). PENERAPAN PEMBELAJARAN BERBASIS DISCOVERY LEARNING MELALUI METODE TALKING STICK UNTUK MENINGKATKAN PEMAHAMAN KONSEP GERAK LURUS. Jurnal EduFisika, 4(2). 
Dani, R., Lestari, N., Pendidikan, P., Universitasjambi, F., \& Artikel, I. (2020). Penelitian ini bertujuan untuk mendeskripsikan kemampuan pedagogical content knowledge mahasiswa Pendidikan Fisika Universitas Jambi yang mengikuti Praktik Lapangan Persekolahan ( PLP ). Jenis penelitian ini yaitu penelitian survey . Populasi penelitian i. Edufisika: Jurnal Pendidikan Fisika, 5.

Hardiyanti, K., Astalini, \& Kurniawan, D. A. (2018). SIKAP SISWA TERHADAP MATA PELAJARAN FISIKA DI SMA NEGERI 5 MUARO JAMBI. Jurnal EduFisika, 3(2).

Jufrida, Basuki, F. R., Pangestu, M. D., \& Prasetya, N. A. D. (2019). ANALISIS FAKTOR YANG MEMPENGARUHI HASIL BELAJAR IPA DAN LITERASI SAINS DI SMP NEGERI 1 MUARO JAMBI. Jurnal EduFisika, 4(2).

Kurnia, N., Hendri, M., \& Pathoni, H. (2016a). Hubungan Persepsi Dengan Hasil Belajar Fisika Siswa Kelas X Mia Di SMA NEGERI 4 KOTA JAMBI dan SMA NEGERI 11 KOTA JAMBI. Jurnal EduFisika, 1(2).

Kurnia, N., Hendri, M., \& Pathoni, H. (2016b). Pendahuluan. 01(02), 55-63.

Kurniawan, D. A., Astalini, A., Kurniawan, N., \& Anggraini, L. (2019). berdasarkan Investigasi dan Korelasi : Kesenangan Belajar dan Minat Meluangkan Waktu pada IPA The Student's Attitude toward Science based on Investigation and Correlation: Learning Fun \& Enthusiasm for Spending Time. Science Education Journal (SEJ), 3(1), 1-13. https://doi.org/10.21070/sej.v3i1.2527

Kurniawan, D. A., Astalini, \& Anggraini, L. (2018a). EVALUASI SIKAP SISWA SMP TERHADAP IPA DI KABUPATEN MUARO JAMBI. Jurnal Ilmiah DIDAKTIKA, 19(1).

Kurniawan, D. A., Astalini, \& Anggraini, L. (2018b). EVALUASI SIKAP SISWA SMP TERHADAP IPA DI KABUPATEN MUARO JAMBI Dwi Agus Kurniawan Pendidikan Fisika, Universitas Jambi , Jambi , Indonesia Astalini Pendidikan Fisika, Universitas Jambi, Jambi , Indonesia Lika anggraini Pendidikan Fisika, Universitas J. 19(1), 124-139.

Kurniawan, D. A., \& Pathoni, H. (2019). Analisis Korelasi Sikap Siswa dan Disiplin Siswa terhadap IPA pada Siswa SMP di Propinsi Jambi. 5(2), 59-71.

Nehru, N., \& Erianti, E. (2019). Analisis hubungan rasa ingin tahu dengan hasil belajar. Jurnal Pembangunan Dan Pndidikan: Fondasi Dan Aplikasi, 7(1).

Nehru, N., \& Irianti, E. (2020). Analisis hubungan rasa ingin tahu dengan hasil belajar. 7(1), 53-59.

Oktaviana, D., Jufrida, \& Darmaji. (2016). PENERAPAN RPP BERBASIS MULTIPE INTELLIGENCES UNTUK MENINGKATKAN AKTIVITAS DAN HASIL BELAJAR FISIKA SISWA PADA MATERI KALOR DAN PERPINDAHAN KALOR KELAS X MIA 4 SMA NEGERI 3 KOTA JAMBI. Jurnal EduFisika, 1(1).

Pakpahan, A. F. P., Ardiana, D. P. Y., Mawati, A. T., Wagiu, E. B., Simarmata, J., Mansyur, M. Z., Ili, L., Purba, B., Chamidah, D., Kaunang, F. J., Jamaludin, \& Iskandar, A. (2020). Pengembangan Media Pembelajaran. Yayasan Kita Menulis.

Pasaribu, Dewi Sasmita, Hendri, M., \& Susanti, N. (2017). Upaya Meningkatkan Minat .... (. 02(01), 61-69.

Pasaribu, Dewi Susmita, Hendri, M., \& Susanti, N. (2017). UPAYA MENINGKATKAN MINAT DAN HASIL BELAJAR FISIKA SISWA DENGAN MENGGUNAKAN MODEL PEMBELAJARAN TALKING STICK PADA MATERI LISTRIK DINAMIS DI KELAS X SMAN 10 MUARO JAMBI. Jurnal EduFisika, 2(1).

Purwanto, A. E., Heendri, M., \& Susanti, N. (2016). Studi perbandingan....(Agus) hal :22-27. 01(01), 22-27.

Putri, A. R., Maison, \& Darmaji. (2018). KERJASAMA DAN KEKOMPAKAN SISWA DALAM PEMBELAJARAN FISIKA DI KELAS XII MIPA SMAN 3 KOTA JAMBI. Jurnal EduFisika, 3(2).

Saputra, W. R., Hendri, M., \& Aminoto, T. (2019). KOLERASI MOTIVASI DAN HASIL BELAJAR IPA SISWA KELAS VIII DI SMP NEGERI SE-KECAMATAN JAMBI SELATAN. Jurnal EduFisika, 4(1).

Utami, S. A., Hendri, M., \& Darmaji. (2017a). HUBUNGAN LINGKUNGAN BELAJAR TERHADAP HASIL 
BELAJAR FISIKA KELAS XI MIA SMA N 1 MUARO JAMBI. Jurnal EduFisika, 2(2).

Utami, S. A., Hendri, M., \& Darmaji. (2017b). random sampling. 02(02).

Yusuf, M., \& Daris, L. (n.d.). Analisis Data Penelitian Teori dan Aplikasi dalam Bidang Perikanan. IPB Press. 